\title{
Harlan Davidson
}

\section{American Business, 1920-2000: How It Worked Thomas K. McCraw \\ Harvard University,}

Graduate School of Business Administration

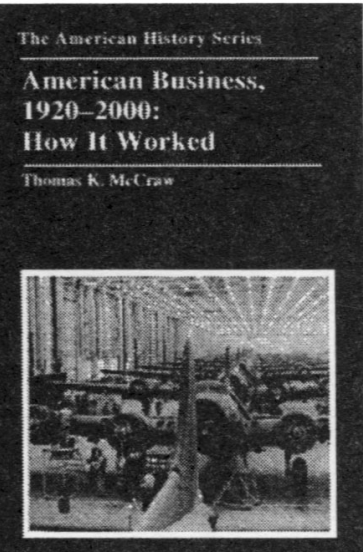

This uncommonly readable book is unique in the market for its breadth of coverage and depth of analysis. Five of its ten chapters provide deft examinations of representative companies and the remarkable people who led them. The firms considered include McDonald's, Procter \& Gamble, Boeing, General Motors, and Ford-all of which began as entrepreneurial startups and grew to become big businesses - their success stories counterbalanced by a detailed dissection of the monumental failure of RCA, long the world leader in consumer electronics but now gone the way of the Dodo.

Unforgettable portraits of dazzling entrepreneurs such as Henry Ford, Alfred Sloan of General Motors, David Sarnoff of RCA, and Ray Kroc of McDonald's are supplemented by lucid sketches of a cast of less famous but equally fascinating characters such as "Doc" Smelser, Mary Kay Ash, Ferdinand Eberstadt, and June Martino.

The book also features five brief "overview" chapters-one each on women and African Americans in business, and three on vital sectors of American business: finance; chemicals and pharmaceuticals; and computers, Silicon Valley, and the Internet-striking photographs, and a comprehensive bibliographic essay. This informative and enjoyable work is destined to become a classic, essential reading for anyone interested in how American business powered the twentieth century and for all students of U.S. business history and the art of administration.

260 pages. Includes Photographs, Bibliographical Essay, and Index. (C) 2000

$20 \%$ professional discount allowed. Visa ana' Mastercard Accepted.

Examination copies available for serious adoption consideration.

HARLAN DAVIDSON, INC. 773 Glenn Avenue •

Wheeling, Illinois 60090-6000 • Phone (847) 541-9720 • Fax

(847) 541-9830 • E-Mail: harlandavidson@harlandavidson.com 


\section{CONSTRUCTING SOCIALISM}

Technology and Change in

East Germany, 1945-1990

Raymond G. Stokes

"A well-structured, convincingly argued book, Constructing Socialism will appeal to

historians of technology and of modern Germany."-Ulrich Wengenroth, Director, Munich Center for the History of Science and Technology, Deutsches Museum

Jolns Hopkins Studies in the History of Technology Merritt Roe Smitl, Series: Editor

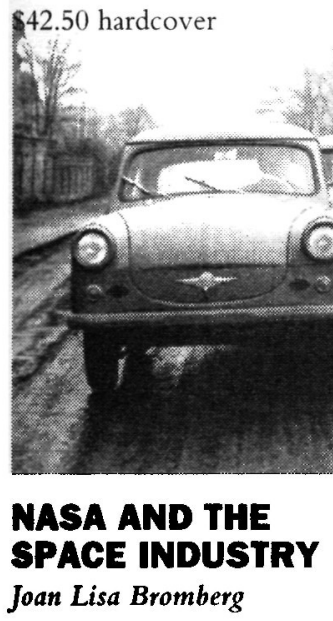

"An important study of a neglected aspect of NASA's history, that is, its relationship with the aerospace industry. which it helped bring into existence. Bromberg is particularly good in her nuanced discussions of how innovations and new jdeas flowed back and forth from the agency to industry, and how the flow was influenced by large changes in the economy and polity."-William H. Becker, George Washington University

New Series in NASA History Ruger D. Launins, Series Editor $\$ 18.95$ paperback

\section{PAPERMAKING IN EIGHTEENTH- CENTURY FRANCE}

Management, Labor, and

Revolution at the

Montgolfier Mill, 1761-18015

Leonard N. Rosenband

"A crisp and extremely wellwritten exploration of the attempts by the Montgolfier family to restructure their paper mills. Its originality lies in its combination of technological history and the investigation of a specific problem in the workplacethe implementation of a new system of recruitment, training, and rewards."-Judith A. Miller. Emory University

\section{RADIO AND TELEVISION REGULATION}

Broadcast Technology in the United States, 1920-1960)

\section{Hugh R. Slotten}

"Slotten effectively uses published primary sources and unpublished archives to discuss the complex interactions bewreen engineers and policy-makers in the United States."-Ronald Kline, Comell University. author of Consuners in the Commery and Steimmet: Engineer and Secialist $\$+5.001$ hardcover

$\$ 39.95$ hardcover

\section{JOHNS HOPKINS}

The Johns Hopkins University Press $1-800-537-5487$ • www.press.jhu.edu 


\section{Encountering Chinese Networks}

Western, Japanese, and Chinese Corporations in China, 1880-1937

\section{SHERMAN COCHAAN}

Cochran calls into question the idea that the spread of capitalism has caused business organizations to converge over time. His cases bring to light numerous organizational forms used by Western. Japanese, and Chinese corporations in China's past, and his conclusions suggest that businesses have experimented with new forms on the basis of their historical experiences - especially their encounters with social networks.

$\$ 40.00$ cloth

At bookstores or order (800) 822-6657
Creating the Corporate Soul The Rise of Public Relations and Corporate Imagery in American Big Business ROLAND MARCHAND
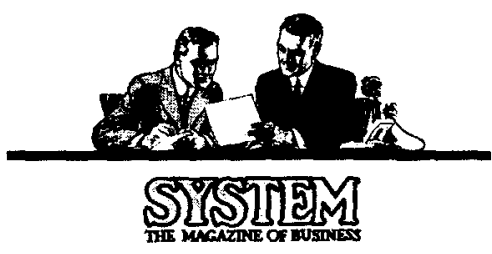

"[Marchand's] conclusion is well earned: big business may not have found a soul but it found a reasonably social facsimile of one."

- New York Times Book Review

$\$ 29.95$ paper

\section{UIIVEnSIT Of EIIFOAIII PRESS}




\title{
Outstanding Scholarship from Cambridge
}

\author{
GLOBAL BUSINESS REGULATION \\ John Braithwaite and Peter Drahos \\ - How has the regulation of business shifted from national to global \\ institutions? \\ What are the mechanisms of globalization? \\ Who are the key actors? \\ What of democratic sovereignty? \\ - In which cases has globalization been successfully resisted?
}

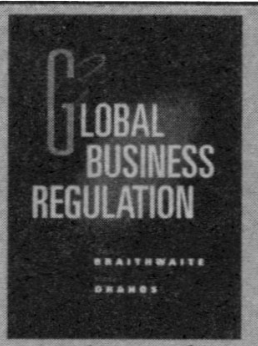

These questions are confronted across an amazing sweep of the critical areas of business regulation-from contract, intellectual property and corporations law, to trade, telecommunications, labor standards, drugs, food, transport and environment. This book examines the role played by global institutions such as the World Trade Organization, World Health Organization, the OECD, IMF, Moodys and the World Bank, as well as various NGOs and significant individuals. Incorporating both history and analysis, Global Business Regulation will become the standard reference for readers in business, law, politics, and international relations.

0-521-78033-0 Hardback $\$ 79.95$

0-521-78499-9 Paperback $\$ 29.95$

\section{INDUSTRIALIZING} ENGLISH LAW

Entrepreneurship and Business Organization, 1720-1844

\section{Ron Harris}

Between 1720 and the mid-nineteenth century, the legal framework of England remained static, while the country went through an economic and social evolution known as the Industrial Revolution. This book addresses the apparent discrepancy between the developing economy of 1720-1844 and the stagnant legal framework of business organization during the same period. The book specifically focuses on the ways by which the legal-economic nexus of the period gave rise to the modern institutions of organizing business.

Political Economy of Institutions and Decisions 0-521-66275-3 Hardback \$59.95

Apailable in bookstores or from

\section{THE STRUGGLE FOR CONTROL OF THE MODERN CORPORATION}

Organizational Change at General Motors, 1924-1970

Robert Freeland

Drawing on primary historical material, The Struggle for Control of the Modern Corporation, provides a historical overview of decision making and political struggle within one of America's largest and most important corporations. Freeland examines the changes in the General Motors organization between the years 1924 and 1970 . He takes issue with the wellknown argument of business historian Alfred Chandler and economist Oliver Williamson, who contend that GM's multidivisional structure emerged and survived because it was more efficient than alternative forms of organization. Structural Analysis in the Sacial Sciences 17 0-521-63034-7 Hardback \$59.95 


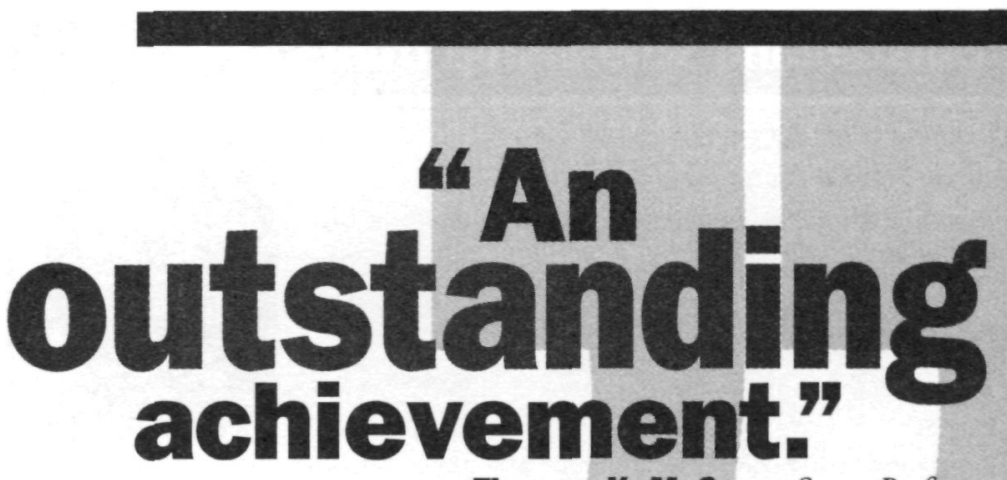

-Thomas K. McCraw, Straus Professor

of Business History, Harvard Business School

Across three centuries, six legendary entrepreneurs have used their uncanny ability to discern how economic and social change would affect consumer needs to create empire-making brands. Through compelling and engaging profiles of these visionaries, Brand New reveals critical and timeless lessons for today's brand builders.

\section{Josiah Wedgwood • Henry Heinz • Marshall Field • Estée Lauder Howard Schultz of Starbucks - Michael Dell}

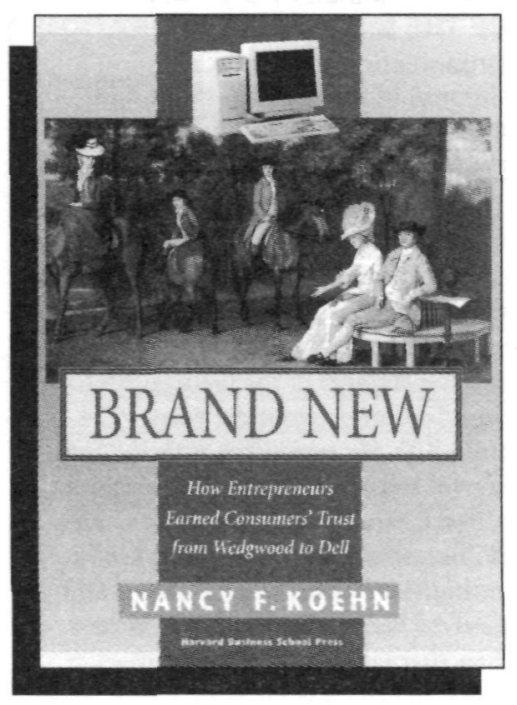

"Koehn has opened a new field of business history-one that focuses on the demand side rather than the supply side in technologically new industries."

-Alfred D. Chandler, Jr., Straus Professor of Business History, Emeritus, Harvard Business School

“A book that gives the vogue word branding a rich and surprising past. Koehn writes with lively prose and has the historian's eye for illuminating detail."

- Jack Beatty, Senior Editor, Atlantic Monthly and Author, Colossus: How the Corporation Changed America

"In this field of study [Nancy Koehn] is the quality brand name." -Ben Wattenberg, Senior Fellow, American Enterprise Institute and Moderator, PBS/Think Tank

$\$ 39.95$ at bookstores everywhere, or call 1-888-500-1016 *1-617-783-7440 Mention priority code 5425 


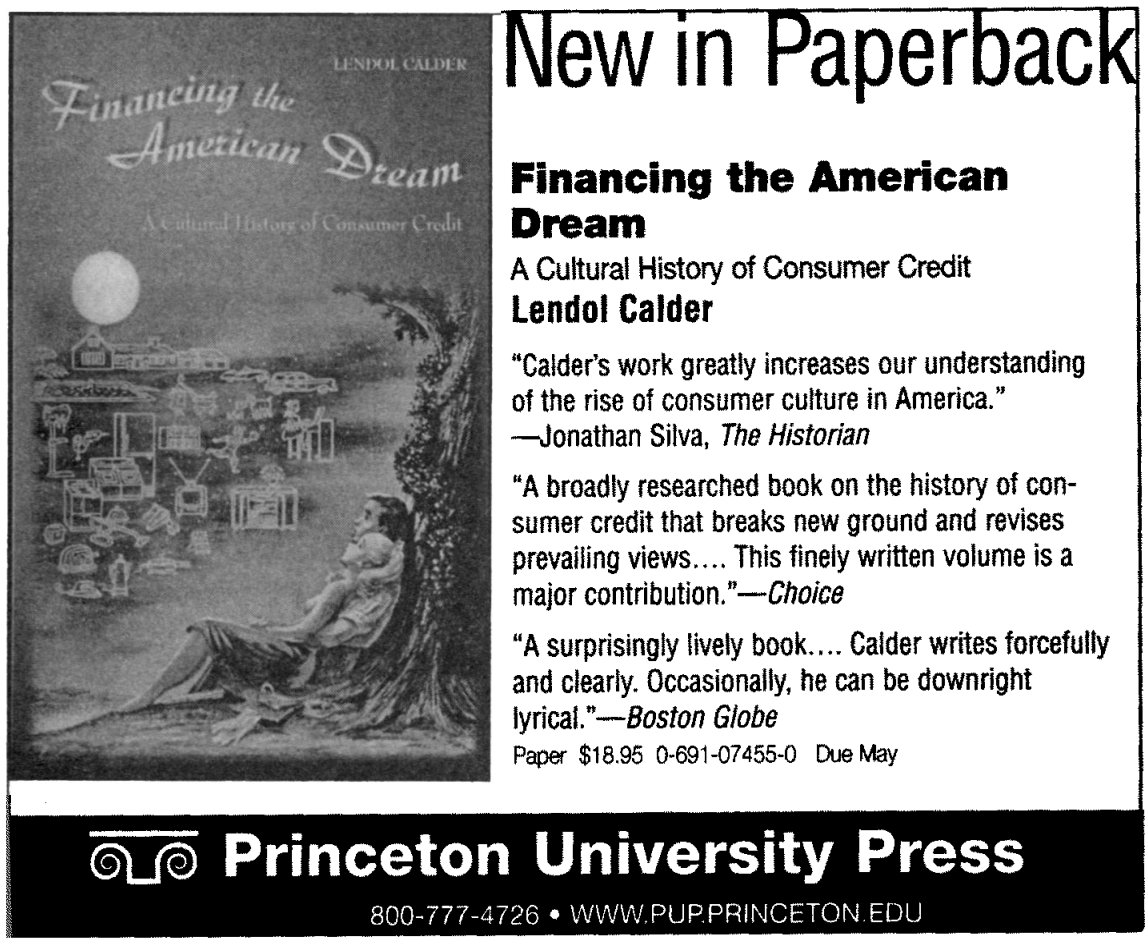




\section{Nor th Carolina}

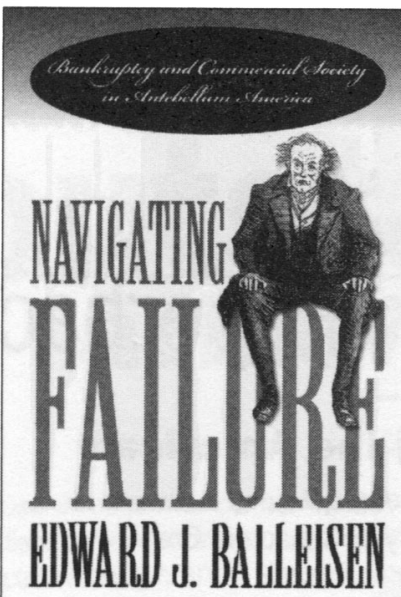

Navigating

Failure

Bankruptcy and

Commercial Society in

Antebellum America

EDWARD I. BALLEISEN

"A richly textured, often riveting portrait of economic risk and the power of entrepreneurial spirit in mid-nineteenth-century America."-Bruce H. Mann, University of Pennsylvania $344 \mathrm{pp}$., 21 illus.

$\$ 49.95 \mathrm{cl} / \$ 18.95 \mathrm{pa}$ Luther Hartwell Hodges Series on Business, Society, and the State

\section{The Most Valuable Asset of the Reich}

A History of the German National Railway Volume 2, 1933-1945

\section{ALFRED C. MIERZEJEWSK!}

"One of the most significant contributions yet to a notable recent literature on the adaptation of businesses to Nazism in order to negotiate their own survival." - Theo Balderston, University of Manchester

$280 \mathrm{pp} . \$ 45.00 \mathrm{cl}$

\section{Internal Improvement}

National Public Works and the Promise of Popular Government in the Early United States JOHN LAURITZ LARSON

"The single most important contribution to our understanding of antebellum American political economy in the last generation." - Peter S. Onuf, University of Virginia

$344 \mathrm{pp}$. \$55.00 cl / \$19.95 pa

\section{Much More Than a Game}

Players, Owners, and American Baseball since 1921

ROBERT F. BURK

"A penetrating and savvy history of baseball's turbulent labor relations." - Andrew Zimbalist, author of Baseball and Billions

384 pp. $\$ 45.00 \mathrm{cl} / \$ 19.95 \mathrm{pa}$

\section{- NEW IN PAPERBACK - \\ Never Just a Game}

Players, Owners, and American Baseball to 1920 ROBERT F. BURK

"A meticulously researched account of the history of labour-management struggles. ... Lively, highly readable ... filled with fascinating anecdotes."

- Business History

302 pp. \$21.95 pa

1994 Macmillan-SABR Baseball Research Award, Society for American Baseball Research

A 1995 Choice Outstanding Academic Book 


\section{GUIDELINES FOR CONTRIBUTORS}

\section{GENERAL INFORMATION}

Manuscripts are considered for publication on the understanding that they are not concurrently under consideration elsewhere and that the material--in substance as well as formhas not been previously published.

Three copies of the manuscript should be submitted.

Authors should identify themselves only on a separate title page that provides name, mailing address, and telephone number. Authors must also remember not to identify themselves in the body of the manuscript; specifically, references to their own work in the text should be in the third person, and citations should be written without possessive pronouns-not "See my ...."

Potential contributors should initially submit hard copy, not diskettes, but it will save considerable work for all parties in the event of acceptance if authors follow a few rules from the beginning:

- In general, use as few formatting commands as possible.

- Left justify text.

- Do not hyphenate words at the end of lines.

- ALL material-including extracted quotations and notes-must be double spaced.

- Notes should be numbered consecutively and citations should be placed as footnotes or endnotes formatted as indicated by The Chicago Manual of Style (1993).

- Each table and figure must be accompanied by a complete source.

Each article should be accompanied by an abstract of 75 to 100 words outlining the main point(s) of the paper and placing the article in context. Subheads should be used to divide the manuscript into three or four sections (or more, depending on length). We do not have an upper or lower page limit, but articles usually run between 25 and 50 typescript pages, including notes and other material.

We are always eager to publish illustrations, but authors should not include originals of illustrative materials at the time of submission; photocopies of such material may be included. Authors are responsible for obtaining all illustrative materials and permissions for reproduction, and for writing captions.

Authors of accepted manuscripts will receive two copies of the issue in which the article appears, and twenty-five offprints.

\section{Manuscript Preparation}

We use the 14th edition of The Chicago Manual of Style (1993) and spell and hyphenate words according to Webster's Ninth New Collegiate Dictionary.

The journal encourages authors to use gender-neutral prose in all cases where it is not anachronistic to do so; male nouns and pronouns should not be used to refer to people of both sexes. We use the day-month-year form for dates, as $11 \mathrm{Feb}$. 1998. Double quotation marks should be used for journal titles and direct quotation; single quotation marks are used for quoted material inside quotations.

\section{Sample Citation Forms}

Book: Alfred D. Chandler, Jr., The Visible Hand: The Managerial Revolution in American Business (Cambridge, Mass., 1977), 321-22.

Journal: Charles Cheape, "Not Politicians but Sound Businessmen: Norton Company and the Third Reich," Business History Review 62 (Autumn 1988): 444-66.

Note that we do not include the publisher in book citations. We do not use loc. cit., op. cit., or idem., but ibid. (not italicized) may be used. 

$0007-6805(200122) 75: 2 ; 1-V$ 